TITLE:

CORAL REEF RECOVERY

FOLLOWING EXTENSIVE DAMAGE

BY THE "CROWN-OF-THORNS"

STARFISH, ACANTHASTER PLANCI

(L.)

$\operatorname{AUTHOR}(S)$ :

Randall, Richard H.

CITATION:

Randall, Richard H.. CORAL REEF RECOVERY FOLLOWING EXTENSIVE DAMAGE BY THE "CROWN-OF-THORNS" STARFISH, ACANTHASTER PLANCI (L.). PUBLICATIONS OF THE SETO MARINE BIOLOGICAL LABORATORY 1973, 20: 469-489

ISSUE DATE:

1973-12-19

URL:

http://hdl.handle.net/2433/175764

RIGHT: 


\title{
CORAL REEF RECOVERY FOLLOWING EXTENSIVE DAMAGE BY THE “CROWN-OF-THORNS" STARFISH, ACANTHASTER PLANCI (L.)
}

\author{
RICHARD H. RANDALL ${ }^{11}$ \\ The Marine Laboratory, University of Guam, Agana, Guam 96910 \\ With 8 Text-figures
}

\begin{abstract}
A recent infestation of the "Crown-of-Thorns" starfish, Acanthaster planci (L.), killed a high proportion of the fringing reefs of Guam. This study is a distributional analysis of the state of the extant coral community to determine whether or not recovery is taking place. The study region is located at Tanguisson Point, Guam, where prior to the starfish predation a well developed fringing reef occurred. This region was heavily infested by an Acanthaster planci population from June, 1968 to September, 1968. The infestation resulted in the death of more than 95 percent of the reef building (hermatypic) corals.

Distributional analysis of the reef corals was undertaken in 1970 with the establishment of three permanent transects in the study area. The distributional analysis includes: 1) species diversity and the relative abundance of each species; 2) percentage of substratum surface occupied by living corals for each reef zone; 3) distribution of corallum size by reef zone; and 4) distribution of coral growth forms by reef zones.

In 1971, one year later, a second distributional analysis of reef corals was conducted on the same transects. A comparison of data from the two periods indicates that some reef recovery is taking place, and changes have occurred in all the above parameters studied. Species diversity has increased in all reef zones. A total of 33 genera and 96 species were recorded in 1970. One year later 38 genera and 111 species were found. Percentage of substratum covered by living corals has increased in all reef zones except the reef margin. Increases in percentage of living coral cover range from 1.6 percent on the seaward slope zone to 3 percent on the submarine terrace and reef front zones. The total number of coral colonies recorded on the transects has increased from 1302 in 1970 to 2116 in 1972. This increase in the number of newly established coral colonies has resulted in a net decrease in average corallum size. There has been an increase in the number of colonies with incrusting growth forms and a decrease in colonies with massive growth forms.
\end{abstract}

\section{Introduction}

Purpose and Scope of the Study: In February, 1967, the coral eating "Crown-ofThorns" starfish, Acanthaster planci (LinNAEus), was noted in above normal population densities, along local portions of the relatively sheltered northern half of Tumon Bay (Fig. 1). The infestation spread to Tanguisson Point located 2.4 kilometers north of

1) Contribution No. 37 from the University of Guam Marine Laboratory. 


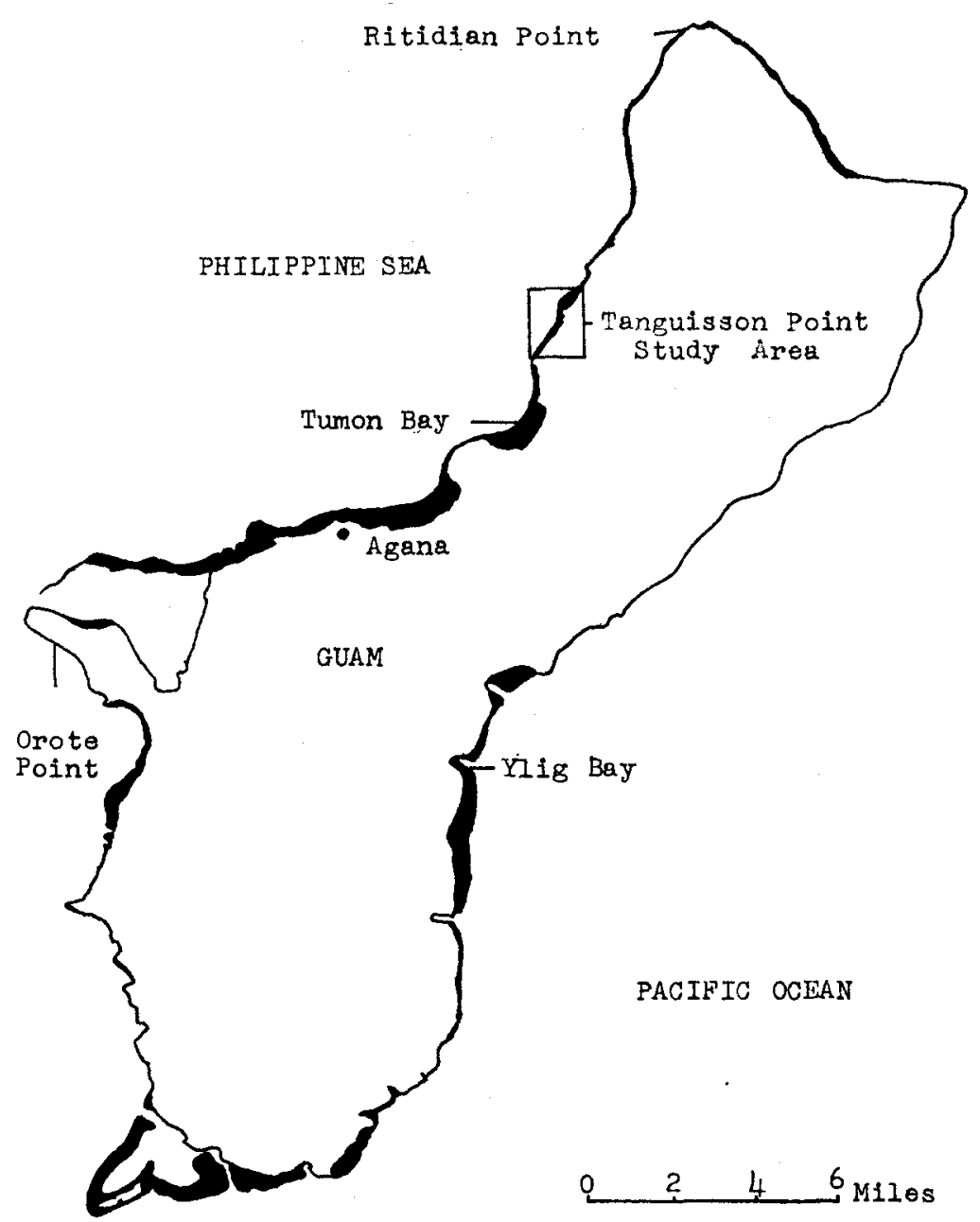

Fig. 1. Fringing reefs of Guam; reef platforms are in heavy black. Map modified from EMERY (1962).

Tumon Bay (Fig. 2), sometime between June, 1968, and September, 1968. By April, 1969, nearly all the starfish had migrated out of the Tanguisson area, leaving over 95 percent of the reef building (hermatypic) corals dead in the area seaward of the reef front zone.

In September, 1969, the University of Guam Marine Laboratory was awarded a grant from the Environmental Protection Agency (Grant No. 18050-EUK) to study the marine environment at the proposed site of the Tanguisson Point electric power generating plant. The facility (Fig. 2) is a fossil-fueled steam plant utilizing seawater, obtained from the reef margin through an open channel, to cool the steam condensers. After passing through the condensers the heated seawater is then piped to an outfall 


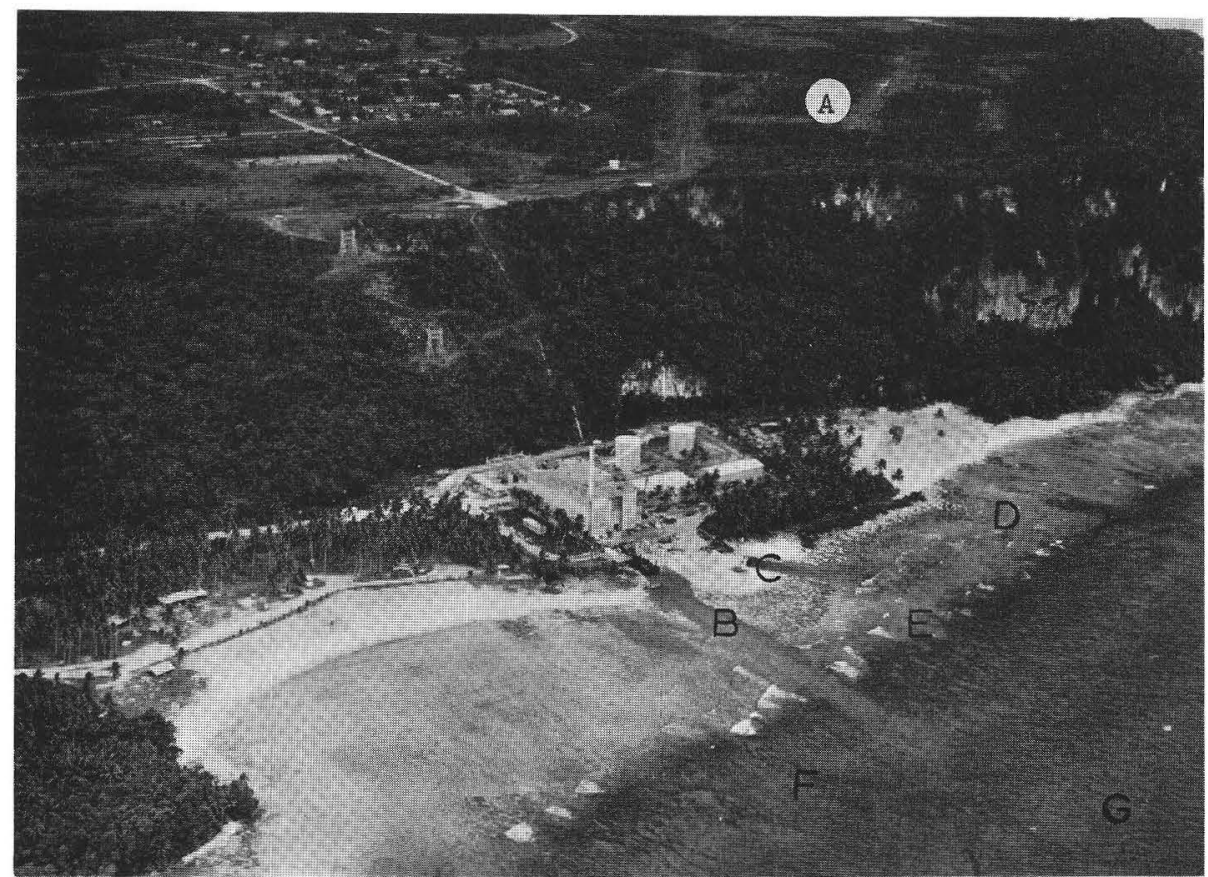

Fig. 2. Aerial view of the Tanguisson Point power plant and study area. Northern limestone plateau (A), intake channel for power plant (B), outfall from the power plant (C), reef flat zone (D), reef margin zone $(E)$, reef front zone $(F)$, and submarine terrace zone $(G)$.

which empties onto the reef platform at the intertidal (littoral) zone (Fig. 2). The primary objective of the grant was to obtain baseline data, before the plant became operational, for use in determining the effects of the heated outfall water upon the fringing reef ecosystem. A secondary objective was to monitor the recovery rate of corals in the reef zones killed by A. planci. The purpose of this study is to assess, over a period of one year, the changes that have occurred in the distribution of the reef corals in the Tumon-Tanguisson region. Three permanent transects were established (Fig. 3) and the first distributional studies conducted in 1970, one year after the initial A. planci infestation. A second study was conducted in 1971, on the same transects, two years after the initial $A$. planci infestation.

Previous Work: Little previous work has been done on the fringing reefs of Guam with respect to coral distribution. Most studies are of a geological nature, dealing mainly with various physical parameters of the reef complex.

Some coral collections were made on Guam and Saipan by CLoud (1954 and 1959), during U. S. geological surveys of these two islands. A list of coral genera was compiled from these collections by Wells (1954). TraceY et al. (1964) conducted several reef traverses in the study area. As far as could be determined, no systematic coral collections were made by TRACEY but several coral genera are listed by reef zones 
from "Reef Traverse 2, at Tumon Bay." The following genera are reported: 1) from the reef margin-Acropora, Pocillopora, Favia, and Millepora; 2) from the reef flat-Porites in the outer part, Acropora, Pavona, and Pocillopora in the inner part. In 1968, RaNDALl (1971) made a distributional analysis of the reef corals at Tumon Bay, prior to the $A$. planci infestation and reported 36 genera and 146 species from the region (Table 1 ).

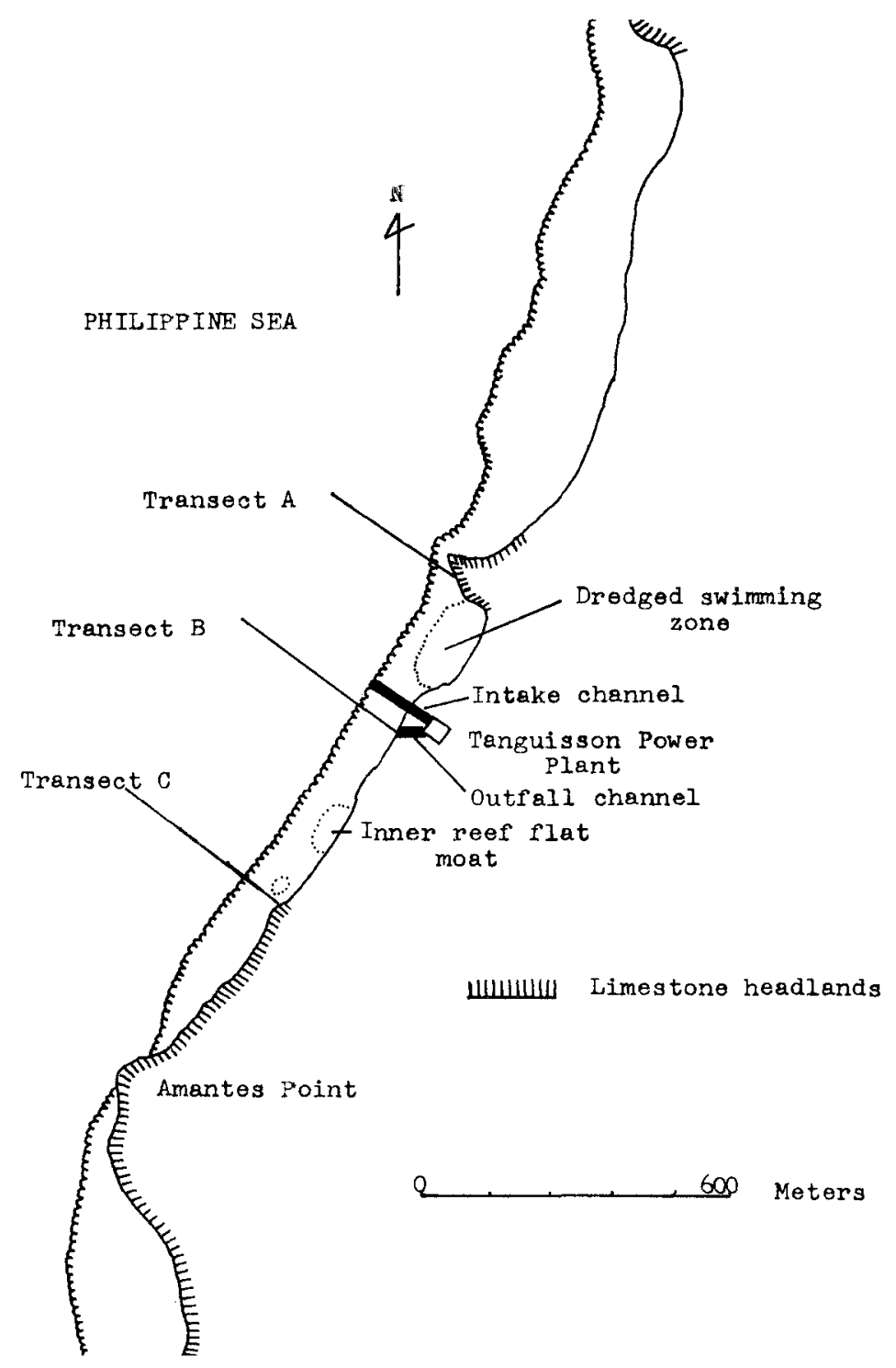

Fig. 3. Detail map of the Tanguisson Point study area showing transect locations. 
Table 1. Check list of corals and their relative frequency of occurrence. Relative frequency for each species is expressed as a percentage of the total number of colonies found on a transect. [ indicates that the species was not found on the transects proper, but was observed in the study area. ( ) indicates a species more or less restricted to the reef flat at Tumon Bay.]

\begin{tabular}{|c|c|c|c|}
\hline & $\begin{array}{l}\text { Tumon Bay } \\
\text { control reef }\end{array}$ & $\begin{array}{l}\text { Tanguisson } \\
\text { Point } 1970\end{array}$ & $\begin{array}{r}\text { Tanguisson } \\
\text { Point } 1971\end{array}$ \\
\hline Stylocoeniella armata (EHRENBERG), 1834 & .36 & 1.69 & .95 \\
\hline Psammocora contigua (ESPER), 1797 & $(5.03)$ & & \\
\hline Psammocora exesa DANA, 1846 & .03 & .15 & \\
\hline Psammocora nierstraszi VAN DER HORST, 1921 & .33 & 1.23 & .71 \\
\hline Psammocora profundacella GARDINER, 1898 & .33 & & \\
\hline Psammocora stellata (VeRRILL), 1866 & (\$) & & \\
\hline Psammocora verrilli $\mathrm{V}_{\mathrm{AUGHAN}}, 1907$ & $\$$ & & \\
\hline Psammocora $(S$.$) togianensis UMBGROVE, 1940$ & .18 & & \\
\hline Psammocora $(P$.$) haimeana MILNE EdWARDS \& HAIME, 1851$ & .03 & .38 & .28 \\
\hline Psammocora sp. 1 & & & .10 \\
\hline Stylophora mordax (DANA), 1846 & .64 & 1.00 & .43 \\
\hline Seriatopora hystrix (DANA), 1846 & .18 & & .05 \\
\hline Pocillopora brevicornis LAMARCK, 1816 & .30 & & \\
\hline Pocillopora damicornis (LINNAEUs), 1758 & $(5.84)$ & & \\
\hline Pocillopora danae VERRILL, 1864 & .12 & & \\
\hline Pocillopora elegans DANA, 1846 & $\#$ & & \\
\hline Pocillopora eydouxi MiLNe Edwards \& HaIME, 1860 & .64 & .15 & .24 \\
\hline Pocillopora ligulata DANA, 1846 & $\$$ & $\#$ & .05 \\
\hline Pocillopora meandrina DANA, 1846 & .79 & 2.61 & 2.98 \\
\hline Pocillopora setchelli HOFFMEISTER, 1929 & 1.12 & 1.77 & .71 \\
\hline Pocillopora verrucosa (Ellis \& SOLANDER), 1786 & 4.03 & 3.23 & 2.36 \\
\hline Pocillopora sp. 1 & & .38 & .38 \\
\hline Acropora abrotanoides (LAMARCK), 1816 & .42 & .54 & .19 \\
\hline Acropora acuminata VERRILL, 1864 & $(5.42)$ & & \\
\hline Acropora arbuscula (DANA), 1846 & (\$) & & \\
\hline Acropora aspera (DANA), 1846 & (10.69) & & \\
\hline Acropora brueggemanni (BROOK), 1893 & .18 & & \\
\hline Acropora convexa (DANA), 1846 & $\#$ & & \\
\hline Acropora cuneata (DANA), 1846 & .03 & & \\
\hline Acropora diversa (BROOK), 1891 & \# & & \\
\hline Acropora humilis (DANA), 1846 & .55 & .61 & .43 \\
\hline Acropora hystrix (DANA), 1846 & .18 & 1.31 & .28 \\
\hline Acropora kenti (BROOK), 1892 & \# & \# & .14 \\
\hline Acropora monticulosa (BRUGGEMANN), 1879 & $\#$ & & \\
\hline Acropora murrayensis VAUGHAN, 1918 & .24 & .92 & .10 \\
\hline Acropora nana (STUDER), 1879 & 2.67 & 2.84 & 3.31 \\
\hline Acropora nasuta (DANA), 1846 & 12.69 & 1.23 & 1.75 \\
\hline Acropora nobilis (DANA), 1846 & $\#$ & & \\
\hline Acropora ocellata (KLUNZINGER), 1879 & .61 & F & .05 \\
\hline Acropora palifera (LAMARCK), 1816 & $\#$ & & \\
\hline Acropora palmerae WELLS, 1954 & .36 & .38 & .47 \\
\hline Acropora rambleri (BASSETT-SMITH), 1890 & $\$$ & & .10 \\
\hline Acropora rayneri (ВROоK), 1892 & $\#$ & & \\
\hline
\end{tabular}


Table 1. (Continued).

\begin{tabular}{|c|c|c|c|}
\hline & $\begin{array}{l}\text { Tumon Bay } \\
\text { control reef }\end{array}$ & $\begin{array}{l}\text { Tanguisson } \\
\text { Point } 1970 \\
\end{array}$ & $\begin{array}{l}\text { Tanguisson } \\
\text { Point } 1971 \\
\end{array}$ \\
\hline Acropora smithi (ВRоoK), 1893 & .55 & .23 & .24 \\
\hline Acropora squarrosa (EHRENBERG), 1834 & \# & $\#$ & $\#$ \\
\hline Acropora studeri (BROOK), 1893 & 1.18 & .84 & .33 \\
\hline Acropora surculosa (DANA), 1846 & 2.06 & .69 & .80 \\
\hline Acropora syringodes (ВRоок), 1892 & .30 & $\#$ & .47 \\
\hline Acropora valida (DANA), 1846 & .39 & .15 & .14 \\
\hline Acropora wardii VERRILL, 1901 & & & .10 \\
\hline Acropora sp. 1 & .79 & .07 & .57 \\
\hline Acropora sp. 2 & .03 & & \\
\hline Acropora sp. 3 & \# & & \\
\hline Astreopora gracilis BERNARD, 1896 & .27 & .31 & .24 \\
\hline Astreopora listeri BERNARD, 1896 & \# & & \\
\hline Astreopora myriophthalma (LAMARCK), 1816 & .15 & .23 & .80 \\
\hline Astreopora sp. 1 & $\#$ & & \\
\hline Montipora acanthella BERNARD, 1897 & (\$) & & \\
\hline Montipora composita CROSSLAND, 1952 & 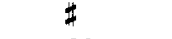 & & \\
\hline Montipora conicula WELLS, 1954 & .39 & .23 & .76 \\
\hline Montipora elschneri VAUGHAN, 1918 & .30 & .76 & .99 \\
\hline Montipora floweri WeLLS, 1954 & $=$ & & \\
\hline Montipora foveolata (DANA), 1846 & .39 & .61 & .10 \\
\hline Montipora granulosa BERNARD, 1897 & & .15 & .05 \\
\hline Montipora hoffmeisteri WeLLs, 1954 & .27 & .07 & .28 \\
\hline Montipora lobulata BERNARD, 1897 & .09 & & \\
\hline Montipora monasteriata (FORSKAAL), 1775 & .27 & 23 & .33 \\
\hline Montipora patula VERRILL, 1869 & $=$ & & \\
\hline Montipora planiuscula DANA, 1846 & (\#) & & \\
\hline Montipora spumosa (LAMARCK), 1816 & $\#$ & & \\
\hline Montipora stilosa (EHRENBERG), 1834 & $=$ & & \\
\hline Montipora tuberculosa (LAMARCK), 1816 & .24 & .23 & \\
\hline Montipora verrilli VAUGHAN, 1907 & 2.51 & 4.99 & 5.39 \\
\hline Montipora verrucosa (LAMARCK), 1816 & .39 & & .24 \\
\hline Montipora sp. 1 & .75 & 1.46 & 2.08 \\
\hline Montipora sp. 2 & .09 & .46 & .24 \\
\hline Montipora sp. 3 & .03 & .61 & 1.65 \\
\hline Montipora sp. 4 & & .38 & .71 \\
\hline Montipora sp. 5 & & .38 & .19 \\
\hline Montipora sp. 6 & & & .28 \\
\hline Montipora sp. 7 & & & .05 \\
\hline Pavona clavus (DANA), 1846 & 1.36 & 1.38 & .19 \\
\hline Pavona decussata (DANA), 1846 & $(.48)$ & & \\
\hline Pavona divaricata (LAMARCK), 1816 & (\$) & & \\
\hline Pavona frondifera (LAMARCK), 1816 & $(\$)$ & & \\
\hline Pavona varians VERRILL, 1864 & .91 & 3.99 & 3.31 \\
\hline Pavona gardineri VAN DER HORST, 1922 & $\#$ & & .10 \\
\hline Pavona $(P$.$) pollicata WeLLs, 1954$ & .21 & .07 & .19 \\
\hline Pavona $(P$.) planulata (DANA), 1846 & .15 & & .47 \\
\hline Pavona $(P$.$) obtusata (QUELCH), 1884$ & .03 & & \\
\hline
\end{tabular}


Table 1. (Continued).

\begin{tabular}{|c|c|c|c|}
\hline & $\begin{array}{l}\text { Tumon Bay } \\
\text { control reef }\end{array}$ & $\begin{array}{c}\text { Tanguisson } \\
\text { Point } 1970\end{array}$ & $\begin{array}{l}\text { Tanguisson } \\
\text { Point } 1971\end{array}$ \\
\hline Pavona (P.) sp. 1 & .45 & & \\
\hline Pavona (P.) sp. 2 & \# & & \\
\hline Pavona (P.) sp. 3 & & .54 & .57 \\
\hline Leptoseris hawaiiensis VAUGHAN, 1907 & .03 & .23 & .05 \\
\hline Leptoseris incrustans (QUELCH), 1886 & .03 & & \\
\hline Leptoseris mycetoseroides WeLLS, 1954 & & & .05 \\
\hline Pachyseris speciosa (DANA), 1846 & 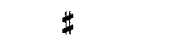 & $\Psi$ & \pm \\
\hline Anomastraea sp. 1 & & & .47 \\
\hline Coscinaraea columna (DANA), 1846 & .18 & .07 & \\
\hline Cycloseris cyclolites (LAMARCK), 1801 & & .23 & \\
\hline Cycloseris sp. 1 & & .15 & .19 \\
\hline Fungia fungites var. incisa DOEDERLEIN, 1902 & \pm & & \\
\hline Fungia fungites var. stylifera DOEDERLEIN, 1902 & .06 & & \\
\hline Fungia scutaria LAMARCK, 1801 & \# & & .05 \\
\hline Goniopora columna DANA, 1846 & \pm & .23 & .19 \\
\hline Goniopora sp. 1 & .21 & & .05 \\
\hline Goniopora sp. 2 & .09 & & .24 \\
\hline Porites annae Crossland, 1952 & $(.09)$ & & \\
\hline Porites australiensis VAUGHAN, 1918 & .42 & .61 & 1.51 \\
\hline Porites cocosensis WeLLS, 1950 & $(.36)$ & & \\
\hline Porites compressa VAUGHAN, 1907 & $(.18)$ & & \\
\hline Porites duerdeni Vaughan, 1907 & $(\sharp)$ & & \\
\hline Porites lichen DANA, 1846 & $\#$ & & .76 \\
\hline Porites lobata DANA, 1846 & 1.67 & 1.08 & 4.73 \\
\hline Porites lutea Milne Edwards \& Haime, 1851 & 2.60 & 3.69 & 2.22 \\
\hline Porites murrayensis VAUGHAN, 1918 & $\#$ & & \\
\hline Porites sp. 1 & 2.79 & 2.23 & .38 \\
\hline Porites sp. 2 & .03 & $\#$ & \\
\hline Porites $(S$.$) convexa VerRILL, 1864$ & .42 & $\#$ & .10 \\
\hline Porites (S.) hawaiiensis VAUGHAN, 1907 & $\#$ & .07 & .85 \\
\hline Porites (S.) horizontalata HOFFMEISTER, 1925 & $\#$ & .07 & \\
\hline Porites (S.) iwayamaensis EGUCHI, 1938 & 1.03 & 1.23 & 1.13 \\
\hline Porites $(S.) \mathrm{sp.} 1$ & $\#$ & & \\
\hline Alveopora verrilliana DANA, 1872 & .09 & $\#$ & \# \\
\hline Favia favus (FoRsKAAL), 1775 & $\#$ & .76 & .24 \\
\hline Favia pallida (DANA), 1846 & .48 & 3.92 & 2.08 \\
\hline Favia speciosa (DANA), 1846 & .30 & & 2.13 \\
\hline Favia stelligera (DANA), 1846 & 2.13 & 5.38 & 3.64 \\
\hline Favia rotumana (GARDINER), 1889 & $\#$ & .15 & .14 \\
\hline Favites abdita (Ellis \& SOLANDER), 1786 & .03 & & \\
\hline Favites complanata (EHRENBERG), 1834 & .67 & 1.31 & 2.08 \\
\hline Favites favosa (EluIS \& SOLANDER), 1786 & & .15 & .14 \\
\hline Favites flexuosa (DANA), 1846 & & .07 & \\
\hline Favites virens (DANA), 1846 & & & .24 \\
\hline Oulophyllia crispa (LAMARCK), 1816 & & & .05 \\
\hline Plesiastrea versipora (LAMARCK), 1816 & .39 & 1.31 & .80 \\
\hline Plesiastrea lilli $\mathrm{WELLS}, 1954$ & & & .05 \\
\hline
\end{tabular}


Table 1. (Continued).

\begin{tabular}{|c|c|c|c|}
\hline & $\begin{array}{l}\text { Tumon Bay } \\
\text { control reef }\end{array}$ & $\begin{array}{l}\text { Tanguisson } \\
\text { Point } 1970\end{array}$ & $\begin{array}{l}\text { Tanguisson } \\
\text { Point } 1971\end{array}$ \\
\hline Plesiastrea sp. 1 & .27 & & \\
\hline Goniastrea parvistella (DANA), 1846 & .46 & 1.31 & .99 \\
\hline Goniastrea pectinata (EHRENBERG), 1834 & & .84 & 1.04 \\
\hline Goniastrea retiformis (LAMARCK), 1816 & 3.48 & 6.68 & 7.14 \\
\hline Platygyra rustica (DANA), 1846 & .39 & .69 & .10 \\
\hline Platygyra lamellina (EHRENBERG), 1834 & & & .05 \\
\hline Platygyra sinensis (MILNE EdWARds \& HaIME), 1849 & .33 & .61 & 1.23 \\
\hline Leptoria gracilis (DANA), 1846 & 1.36 & 2.53 & 1.23 \\
\hline Leptoria phrygia (ELLIS \& SOLANDER), 1786 & .09 & 2.30 & .80 \\
\hline Hydnophora microconos (LAMARCK), 1816 & .33 & .07 & .14 \\
\hline Leptastrea bottae (MILNE EdWARDS \& HAIME), 1849 & $\Psi$ & & \\
\hline Leptastrea purpurea (DANA), 1846 & 2.27 & 2.46 & 4.40 \\
\hline Leptastrea transversa (KLUNZINGER), 1879 & & 1.31 & 1.65 \\
\hline Leptastrea sp. 1 & .21 & 1.08 & 3.97 \\
\hline Cyphastrea chalcidicum (FORSKAAL), 1775 & & & .28 \\
\hline Cyphastrea serailia (FORSKAAL), 1775 & .36 & .07 & 1.13 \\
\hline Cyphastrea sp. 1 & .51 & .46 & \\
\hline Echinopora lamellosa (ESPER), 1787 & .09 & .38 & .10 \\
\hline Diploastrea heliopora (LAMARCK), 1816 & .09 & 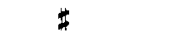 & .14 \\
\hline Galaxea fascicularis (LINNAEUs), 1758 & .24 & 1.38 & .14 \\
\hline Galaxea hexagonalis MILNE EdWARds \& HaIME, 1857 & 2.36 & 8.29 & 7.69 \\
\hline Merulina ampliata (ELLIS \& SOLANDFR), 1786 & & & .05 \\
\hline Lobophyllia corymbosa (FORSKAAL), 1775 & .27 & .31 & .14 \\
\hline Lobophyllia costata (DANA), 1846 & .21 & .46 & .19 \\
\hline Acanthastrea echinata (DANA), 1846 & .48 & 2.53 & .71 \\
\hline Echinophyllia asper Elurs \& SOLANDER, 1786 & & .23 & .85 \\
\hline Mycedium sp. 1 & & & .14 \\
\hline Paracyathus sp. 1 & \# & & \\
\hline Polycyathus sp. 1 & $\#$ & & \\
\hline Euphyllia glabrescens (CHAMISSO \& EYSENHARDT), 1821 & \# & & \\
\hline Heliopora coerulea (PALLAS), 1766 & .24 & .07 & .10 \\
\hline Millepora dichotoma FORSKAAL, 1775 & .18 & .07 & $\#$ \\
\hline Millepora exaesa FoRSKAAL, 1775 & .88 & 1.15 & 1.94 \\
\hline Millepora platyphylla HEMPRICH \& EHRENBERG, 1834 & 1.12 & 1.77 & 1.23 \\
\hline \multirow[t]{2}{*}{ Distochopora violacea (PALLAS), 1776} & .09 & .38 & .14 \\
\hline & $100 \%$ & $100 \%$ & $100 \%$ \\
\hline Total number of colonies & 3302 & 1302 & 2116 \\
\hline
\end{tabular}

Other work on the reefs of Guam was done by StEARns (1940), Cloud (1951), and TAYama (1952). Coral distribution was not included in these studies. A study of the marine geology of Guam by EMERY (1962) includes investigations of submarine slopes, lagoon floors, channels through fringing reefs, beaches, and rocky shores.

The first observation of an infestation of $A$. planci on Guam was made in the Tumon Bay-Tanguisson Point region in 1967 by Randall (1971). These and other observations were first reported by CHESHER (1969a and 1969b). CHESHER describes 
A. planci population movements, densities, feeding behaviour, relative coral predation rates, control measures, and possible causative factors related to the sudden increase in numbers of starfish in various Indo-Pacific regions. TsudA (1971) describes the current status of $A$. planci on Guam with regard to population densities, location of infested reefs, and an extent of the coral damage.

General Description of the Study Area and Control Area: The fringing reef flat platform along this section of coastline is relatively narrow (Figs. 1 and 2) and is bordered by steep limestone slopes and cliffs (Fig. 2). The reef flat platform ranges in width from 70 meters at Transect A to 110 meters at Transect C. TRACEY et al. (1964) decribes this region of coastline as possessing well developed fringing reefs with a luxuriant growth of corals.

In order to establish coral recovery rates for the Tanguisson Point study area it was necessary to use data from the distributional work done by RaNDALL (1971) at Tumon Bay. This work shows that with the exception of the reef flat platform, the reef zones at Tumon Bay and Tanguisson Point were fairly similar in respect to coral distributional, topographical, and developmental features. Because of these similarities and the previous coral distributional studies conducted there, the Tumon Bay reef is used as a control to establish baseline data for determining the degree of coral reef recovery at Tanguisson Point.

At Tanguisson Point the greatest $A$. planci damage to reef corals was more or less restricted to the seaward slope, submarine terrace, and the outer part of the reef front zones. Some local damage occurred on the inner half of the reef front and the reef margin zones. Acanthaster damage followed a similar pattern at Tumon Bay except for the reef margin and inner part of the reef front zones, where reduced wave and surf activity found there enabled the starfish to more effectively attach to the corals in these zones.

\section{Methods}

Three permanent transects (A, B, and C) were established at right angles to the reef margin at Tanguisson Point (Fig. 3). Stations were established at 10 meter intervals along the transect lines from the intertidal (littoral) zone to a depth of 30 meters on the seaward slope zone (Fig. 4). These station locations were permanently marked by placing three to five links of ship anchor chain ( 4.7 kilograms per link) at each. Stations were identified by attaching numbered fiberglass cards to the anchor chain links. For ease in locating the transect stations the numbered cards were suspended approximately 0.5 meters above the anchor links by a plastic float (Fig. 5). At each station a reference point was established at the point where the numbered card was attached to the anchor links.

Two wire grid quadrats, each one meter square, were positioned at the station reference point. To insure placement of the quadrat grids at the same location, during 


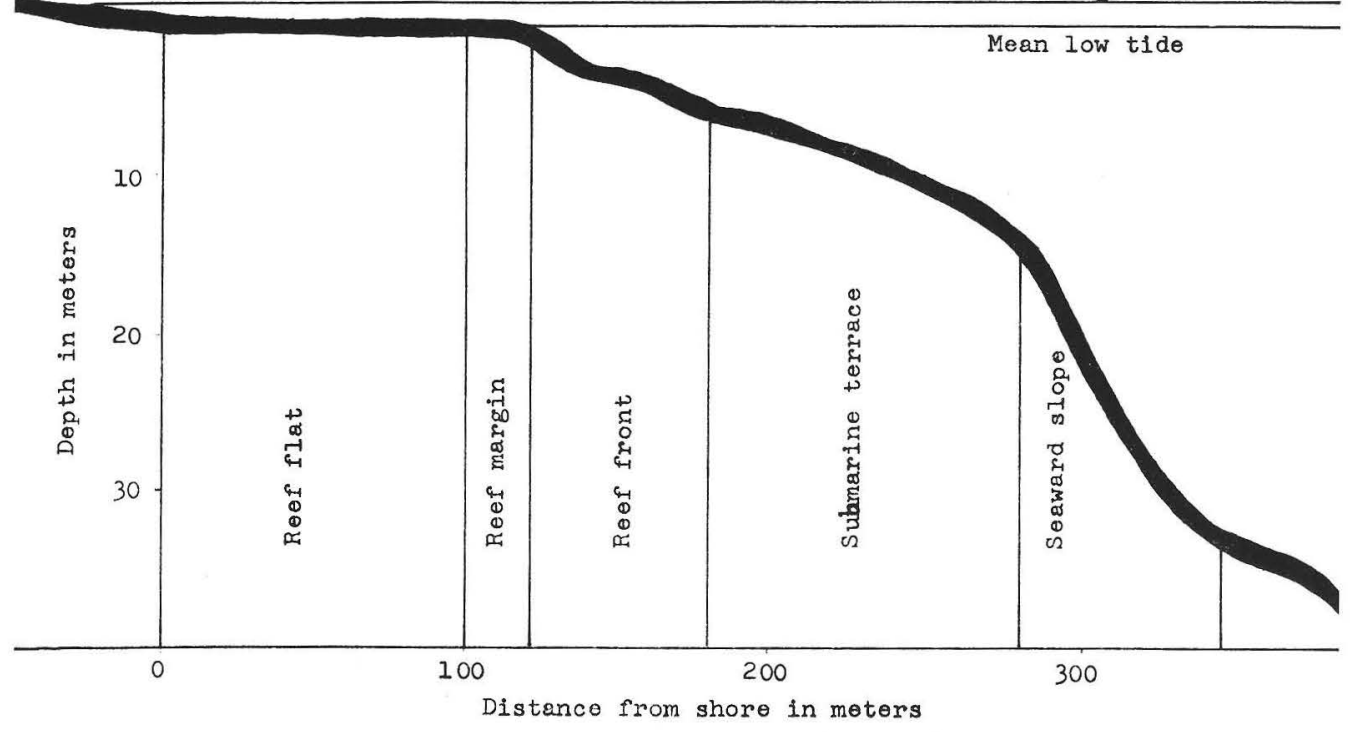

Fig 4. Reef profile of Transect $B$ at Tanguisson Point. Vertical exaggeration $\times 5$.

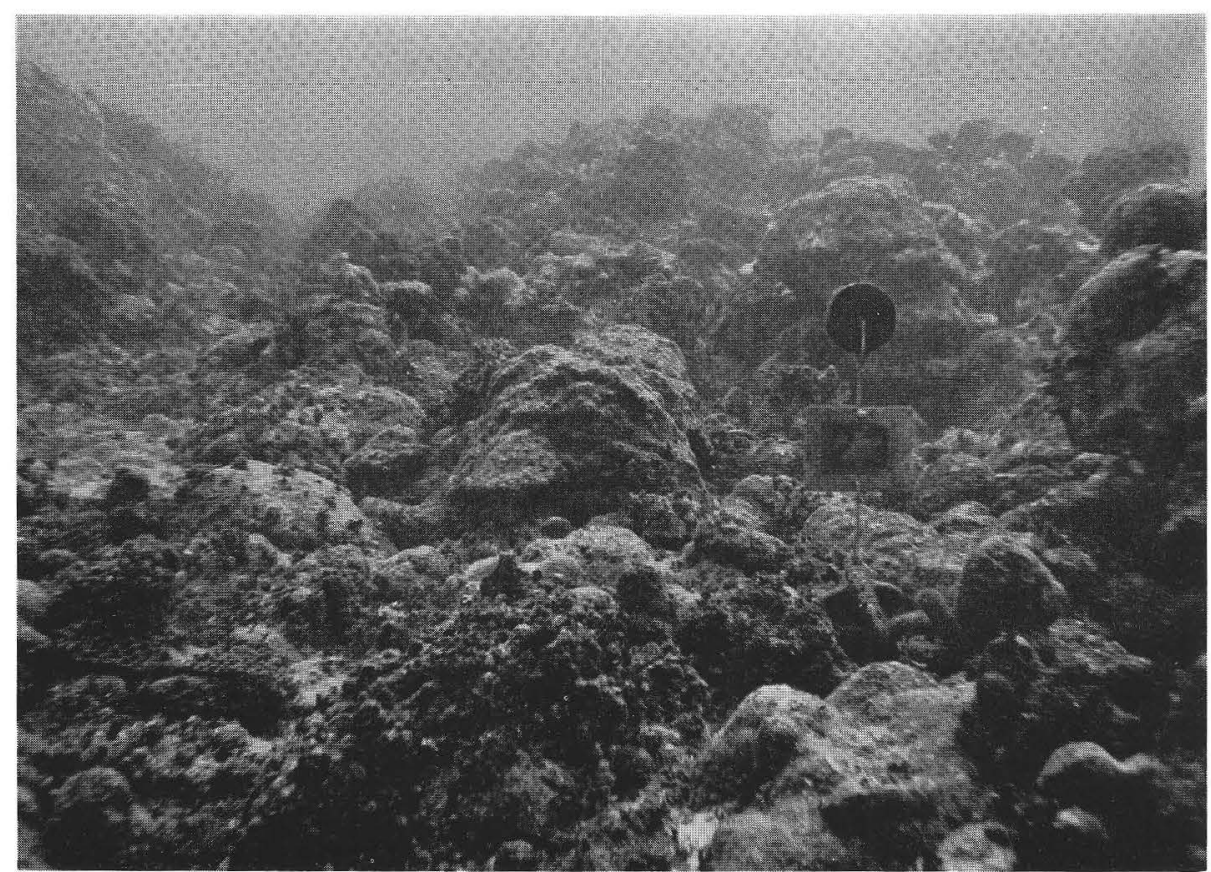

Fig. 5. Transect station showing anchor links and station number suspended by a float. The location is on Transect B in the submarine terrace zone. The outer part of the reef front is visible in the background. Ninety percent or more of the coral colonies visible have been killed by Acanthaster planci and most are still intact and in position of growth. 
each study period, the seaward adjacent corner of each grid was placed on the reference point. The adjacent sides of these two grids were then visually aligned with the next shoreward station marker. Facing in a shoreward direction the right and left hand quadrats were given the numbers one (1) and two (2) respectively. After positioning of the quadrat grids the following data were recorded from each: 1) the transect station number; 2) the quadrat number; and 3) the specific name, size, and growth form of each living coral found within the confines of the grid.

Various coral growth forms listed in Table 6 follows, for the most part, those described by WeLLS (1956). A columnar form was added which differentiates an intermediate mode of development between the massive and ramose forms. Ramose forms were subdivided into corymbose, cespitose, and arborescent modes of branching.

Size measurements of coral colonies were determined by using a meter stick with moveable trammel points. If the coral colony was more or less circular, measurement was made at the widest point across the corallum. If the colony was irregular, its outline was sketched and several measurements of length and width were recorded.

For the purpose of coral distributional analysis the fringing reef platform and offshore slopes were divided into zones based on those described by TRACEY et al. (1964). These zonal divisions (Figs. 2 and 4) are based on various physical parameters such as degree of reef surface exposure at high tide, degree of reef surface submergence at low tide, amount of submarine slope, and reef topographical features which are controlled by growth and erosional processes.

Transect locations were based upon the location of the power plant outfall site (Fig. 3). To study the direct effects of the heated water, Transect B was placed at the outfall site itself. Since the inshore current patterns were not known at Tanguisson Point, two control transects, one on each side of the outfall site, were established (Fig. 3). Lengths of the transects vary, because of slight differences in submarine topography, as follows: 1) Transect A, 300 meters with 30 stations; 2) Transect B, 330 meters with 33 stations; and 3) Transect C, 290 meters with 29 stations. Figure 4 is a cross sectional profile of Transect $B$ and shows the location of the various reef zones with respect to depth.

\section{Results and Discussion}

The first distributional analysis of the reef corals was made during the first six months of 1970, and the second analysis during the same period in 1971. Living corals were found at 59 stations in 1970, and at 65 stations in 1971 (Fig. 6). In regard to stations with living corals present from 1970 to 1971, there was a gain and a loss of one station each on the outer reef flat zone, a loss of one station on the reef margin zone, and a gain of seven stations on the seaward slope zone. During the 1970 study, 1302 living corals were found within the confines of the quadrat stations and one year later, 1971, the number had risen to 2116 . Nearly 82 percent of these new coral 
colonies have settled in the submarine terrace and seaward slope zones. Settlement of most of the remaining new colonies took place on the outer half of the reef front zone. Species Composition: Table 1 lists the coral species composition along with their relative frequency of occurrence on the fringing reef at Tanguisson Point during the 1970 and 1971 study periods and for the Tumon Bay control reef studied in 1968 . At the control reef 15 species are more or less restricted to the reef flat zones (Table 1). These restricted species would not be expected to occur at Tanguisson Point because the reef flat zones are poorly developed there and a well defined inner reef flat "moat" is absent. For comparative purposes, then, the total number of species at the control reef should be reduced to the 131 which could be found in equivalent zones at Tanguisson Point.

Table 1 shows that of a total of 96 species and 33 genera found at Tanguisson point during 1970, all but nine species and one genus were found again in 1971. There were 23 species and 6 genera of corals new to the Tanguisson transects in 1971. Of these new corals, 12 are also new to the Tumon Bay control reef. At Tanguisson Point, from 1970 to 1971, the relative frequency of occurrence (Table 1) decreased for 51 species, increased for 34 species, and remained unchanged for 1 species.

Table 2. Number of genera and species for the major groups of corals found at Tumon Bay (1968), Tanguisson Point (1970), and Tanguisson Point (1971). Values enclosed by parentheses indicate the number of coral genera and species found only on the transect stations. Values not enclosed by parentheses indicate the number found on the transect stations plus additional genera and species found by making observations of the reef surface located between Transect $A$ and Transect C.

\begin{tabular}{lrrrrrr}
\hline & \multicolumn{2}{c}{$\begin{array}{c}\text { Tumon Bay } \\
\text { Control Reef (1968) } \\
\text { Genera }\end{array}$} & Species & \multicolumn{2}{c}{$\begin{array}{c}\text { Tanguisson Point } \\
(1970)\end{array}$} & \multicolumn{2}{c}{$\begin{array}{c}\text { Tanguisson Point } \\
\text { Genera }\end{array}$} & Species & \multicolumn{2}{c}{$\begin{array}{c}\text { Genera } \\
\text { S1971) }\end{array}$} & Species \\
\hline $\begin{array}{l}\text { Hermatypic } \\
\quad \text { Scleractinians }\end{array}$ & $31(29)$ & $139(98)$ & $30(27)$ & $91(81)$ & $35(33)$ & $106(103)$ \\
$\begin{array}{l}\text { Ahermatypic } \\
\quad \text { Scleractinians }\end{array}$ & $2(0)$ & $2(0)$ & $0(0)$ & $0(0)$ & $0(0)$ & $0(0)$ \\
$\begin{array}{l}\text { Non-Scleractinians } \\
\text { Totals }\end{array}$ & $3(3)$ & $5(5)$ & $3(3)$ & $5(5)$ & $3(3)$ & $5(4)$ \\
\hline
\end{tabular}

For the reef as a whole, Table 2 shows that the total number of genera has increased by' five at Tanguisson Point from 1970 to 1971 . This increases the total number of genera found at Tanguisson Point in 1971 to 38, which is greater than the total of 36 found at the Tumon Bay control reef prior to the $A$. planci infestation period. The same table shows an increase of 15 species from 1970 to 1971 at Tanguisson Point, but unlike the number of genera which now surpasses that found at the Tumon Bay control reef, the number of species is still 20 below the 131 found prior 
to the starfish infestation period.

A zonal analysis (Table 3) shows very little change in the number of genera and species on the inner reef flat, reef margin, and reef front zones. Only small changes should be expected in these zones since there has been comparatively little Acanthaster damage to the corals on this part of the reef. Greatest changes have occurred in the submarine terrace and seaward slope zones where Acanthaster predation on corals was more intense.

Table 3. Changes in the number of coral genera and species by reef zones at Tanguisson Point from 1970 to 1971 . Values enclosed by parentheses indicate the number of coral genera and species found only on the transect stations. Values not enclosed by parentheses indicate the number found on the transect stations plus additional genera and species found by making observations of the reef surface located between Transect $\mathrm{A}$ and Transect $\mathrm{C}$.

\begin{tabular}{|c|c|c|c|c|}
\hline \multirow[t]{2}{*}{ Reef Zones } & \multicolumn{2}{|c|}{ Tanguisson Point 1970} & \multicolumn{2}{|c|}{ Tanguisson Point 1971} \\
\hline & Genera & Species & Genera & Species \\
\hline Inner reef flat & $0(0)$ & $0(0)$ & $0(0)$ & $0(0)$ \\
\hline Outer reef flat & $2(2)$ & $2(2)$ & $4(1)$ & $5(2)$ \\
\hline Reef margin & $12(12)$ & $21(21)$ & $10(10)$ & $21(20)$ \\
\hline Reef front & $24(24)$ & $70(65)$ & $21(21)$ & $68(67)$ \\
\hline Submarine terrace & $24(22)$ & $47(45)$ & $27(27)$ & $70(70)$ \\
\hline Seaward slope & $21(19)$ & $32(28)$ & $30(30)$ & $61(61)$ \\
\hline
\end{tabular}

Figure 6 shows the number of genera and species for each transect by stations and reflects more exactly where changes have occurred. Two artifacts are present in Fig. 6. The first is at Transect $A$ on the reef margin zone and the second at Transect $B$ on the reef margin and inner (shoreward) part of the reef front zones. At both of these transect locations a reduction in the number of genera and species has occurred. At Transect A this reduction was caused by a bloom of a bluegreen alga, Anacystis dimidiata DrouET and DAILY, which, in a small localized region, covered nearly 100 per cent of the reef surface. Many corals were killed as a result of their living tissues being covered by gelations shards of this alga. At Transect $B$ the reduction was caused by the presence of heated effluent from the power plant outfall. Transect B bisects a portion of the outfall plume. Nearly all the corals have been killed on the reef margin and inner (shoreward) part of the reef front zones. Figure 6 graphs, otherwise, show that greatest changes in the number of genera and species has taken place on transect stations located on the submarine terrace and seaward slope zones. An analysis of Fig. 6 reveals that: 1) for the 23 stations at Transect A, where living corals were found, the generic total has increased at 15 , decreased at 6 , and remained unchanged at 2 , and the specific total has increased at 18 and decreased at $5 ; 2$ ) for the 24 stations at Transect B, where living corals were found, the generic total has increased at 17 , decreased at 5 , and remained unchanged at 1 , and the specific total has increased at 18 , decreased at 4 , and remained unchanged at 2; and 3) for the 20 stations at Transect 

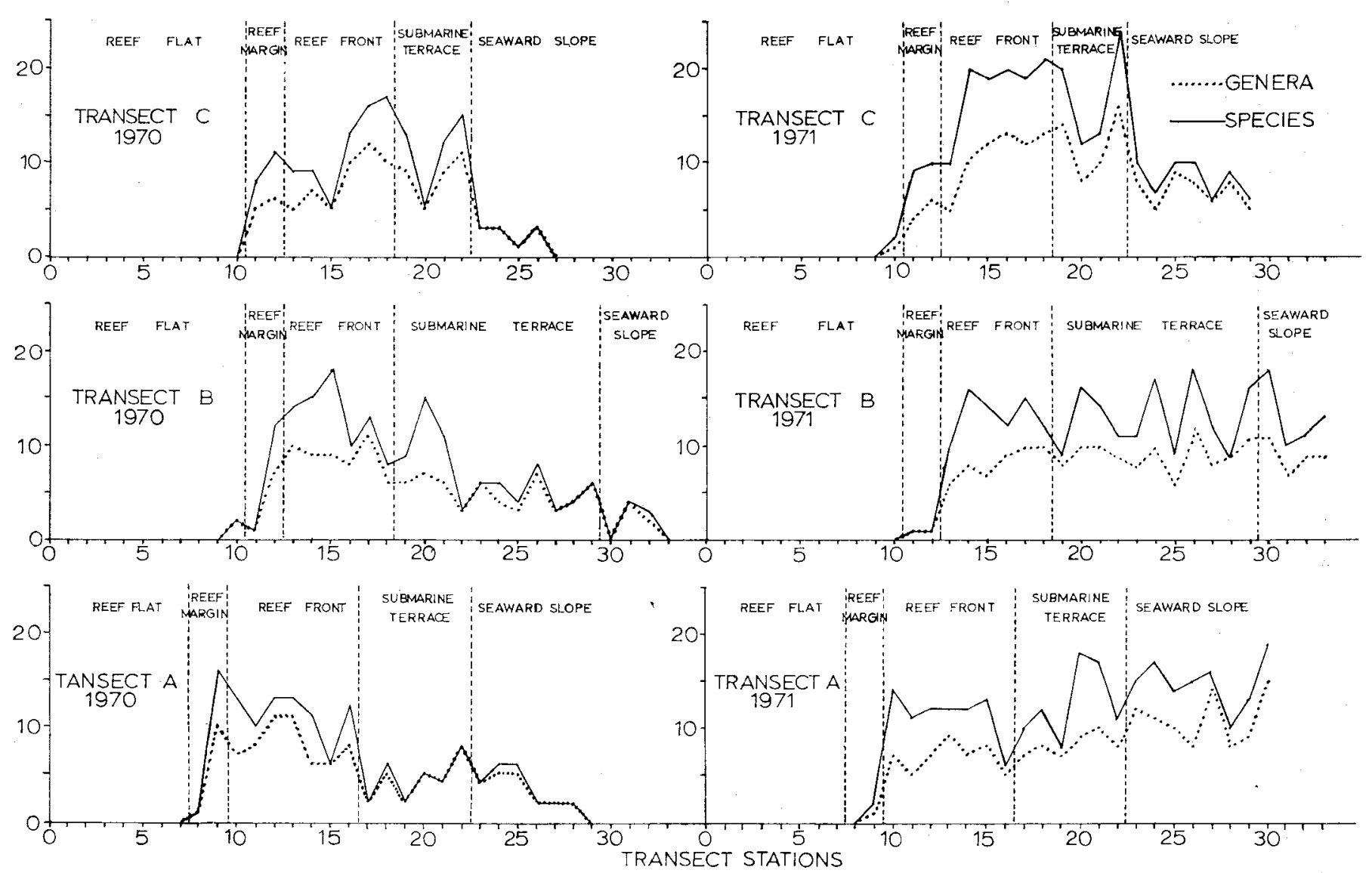

Fig. 6. Number of coral genera and species per transect station from 1970 to 1971. Dotted lines represent genera and solid lines species. 
$\mathrm{C}$, where living corals were found, the generic total has increased at 16 , decreased at 1 , and remained unchanged at 3 , and the specific total has increased at 19 and decreased at 1 .

It appears, then, that species diversity is increasing fairly rapidly at Tanguisson Point, which is due in part, to the recolonization of not only the former species which commonly occurred there, but also to species that do not normally occur in the area. Possibly the corals new to the area represent a pioneer group which recolonize the reef surface recently killed by Acanthaster predation. PORTER (1971) reported a similar phenomenon on the west coast of Panama where corals were killed by Acanthaster. As more reef surface becomes covered with living corals, especially by those species which formerly occupied the region, interspecific competition may well become an important factor which could, again, restore the pre-Acanthaster species composition to the reef. Until competition becomes a limiting factor at Tanguisson Point, species diversity could go beyond the 131 level found previously at Tumon Bay.

Table 4. Changes in the percentage of reef surface covered by living coral by reef zones from 1970 to 1971 at Tanguisson Point.

\begin{tabular}{|c|c|c|c|c|c|c|}
\hline \multirow[t]{2}{*}{ Reef Zone } & \multicolumn{2}{|c|}{ Transect $\mathrm{A}$} & \multicolumn{2}{|c|}{ Transect B } & \multicolumn{2}{|c|}{ Transect $\mathrm{C}$} \\
\hline & 1970 & 1971 & 1970 & 1971 & 1970 & 1971 \\
\hline Outer reef flat & $0.0 \%$ & $0.0 \%$ & $0.0 \%$ & $0.0 \%$ & $0.0 \%$ & $0.0 \%$ \\
\hline Inner reef flat & $0.0 \%$ & $0.0 \%$ & $0.1 \%$ & $0.0 \%$ & $0.0 \%$ & $1.0 \%$ \\
\hline Reef margin & $17.5 \%$ & $0.1 \%$ & $28.0 \%$ & $1.5 \%$ & $22.2 \%$ & $25.0 \%$ \\
\hline Reef front & $5.1 \%$ & $8.7 \%$ & $39.0 \%$ & $32.2 \%$ & $18.8 \%$ & $24.8 \%$ \\
\hline Submarine terrace & $0.7 \%$ & $2.7 \%$ & $1.1 \%$ & $4.9 \%$ & $1.0 \%$ & $4.3 \%$ \\
\hline Seaward slope & $0.9 \%$ & $3.0 \%$ & $0.2 \%$ & $1.8 \%$ & $0.5 \%$ & $1.6 \%$ \\
\hline
\end{tabular}

Reef Surface Coverage by Living Corals: The percentage of living coral covering the reef surface (Table 4) has increased on all transects and reef zones except for the reef margin on Transect A and the outer reef flat, reef margin, and reef front on Transect B. Reduction of reef surface coverage in these zones is due to the Anacystis dimidiata bloom on Transect A and the presence of the outfall plume at Transect B. Transect C, located well south of the outfall plume, shows a gain in living coral coverage in all reef zones. Figure 7 shows the percent of coral coverage for each station on the three transects and indicates that the highest relative gains have taken place in the submarine terrace and seaward slope zones where $A$. planci damage to the reef corals was greatest.

Description of the Coral-kill at Transect B: Figure 8 shows coral colonies in the reef margin zone, at Transect $B$, that have recently been killed by effluent from the power plant outfall. Although heated outfall water has a tendency to float on the surface of the cooler ambient seawater, observations show (Fig. 8) that the corals killed in this zone extend not only from the upper surfaces of the buttresses, which 


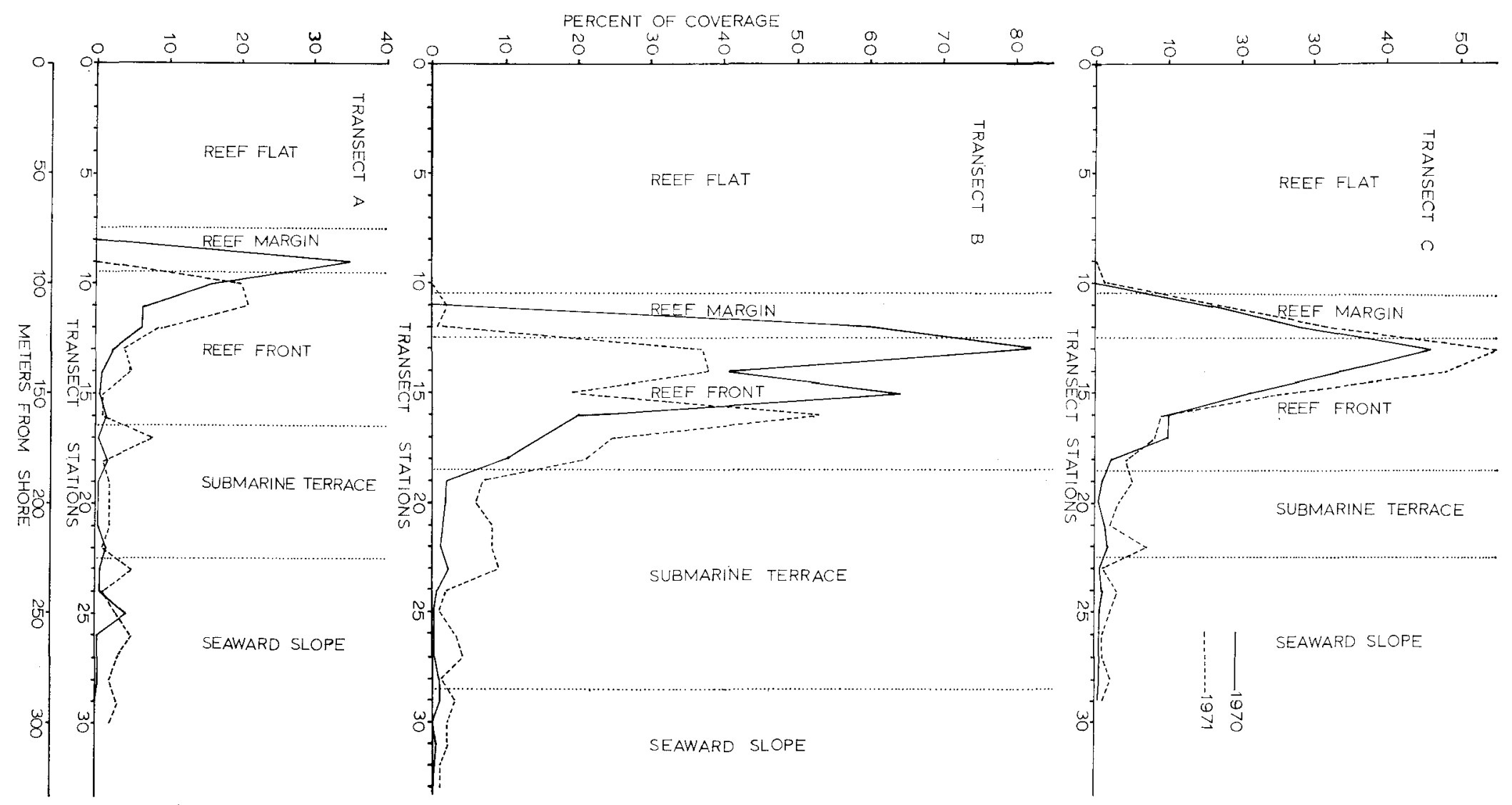

Fig. 7. Percentage of reef surface covered by living corals from 1970 to 1971 . Dashed line represents 1971 and the solid line 1970. 


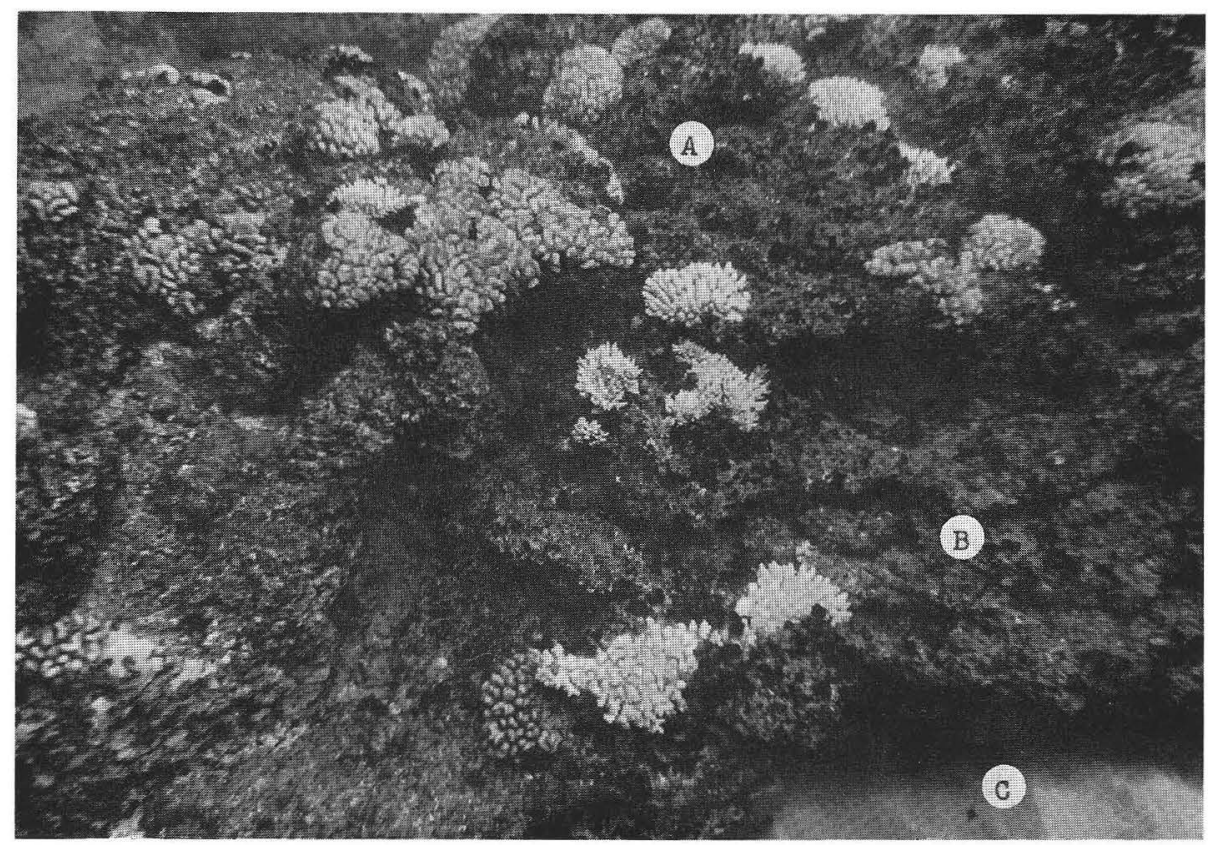

Fig. 8. Corals killed by the outfall effluent at Transect B. This view shows the white skeletons of pocilloporid and acroporid corals that were growing on the upper surface (A) of a reef front spur and wall (B) of a submarine groove. Unconsolidated sediments are visible on the groove floor at (C).

would be exposed to the upper layer of outfall water, but also to the deeper surge channel walls and floors. Temperature data indicates that wave and surf action mixes the outfall water in the reef margin zone, therefore extending the vertical range in which corals are killed. Seaward of the surf zone the warmer outfall water becomes stratified and is generally restricted to the upper one meter water layer. It has little effect on the living corals, since the water depth there is usually greater than one meter, except where the upper parts of coral knobs, bosses, and pinnacles extend up into this one meter layer.

Corallum Size Distribution: Table 5 lists the frequency distribution of corals by diameter for each reef zone from 1970 to 1971. The greatest change in size distribution occurred in the $0-5 \mathrm{~cm}$ range, where a 55 percent increase took place. This large increase is due mainly to the new settlement and growth of coral planulae on the algal incrusted surface of corals, previously killed by $A$. planci. Even though this large increase took place between 1970 and 1971, 62 percent of the corals were also found in the $0-5 \mathrm{~cm}$ range in 1970 . Most of these colonies were represented, at that time, by small patches of coralla, surviving from larger colonies, that were not completely killed by $A$. planci. The second largest increase was in the $6-10 \mathrm{~cm}$ range which mostly represents an increase in growth of the surviving coral patches described above, 
Table 5. Distribution of corals by diameter at Tanguisson Point from 1970 to 1971. Data from transects $\mathrm{A}, \mathrm{B}$, and $\mathrm{C}$ are combined.

\begin{tabular}{|c|c|c|c|c|c|c|c|c|c|c|c|c|}
\hline \multirow{2}{*}{$\frac{\text { Reef zones }}{\text { Dia. range }}$} & \multicolumn{2}{|c|}{ Outer } & \multicolumn{2}{|c|}{ Reef margin } & \multicolumn{2}{|c|}{ Reef front } & \multicolumn{2}{|c|}{$\begin{array}{l}\text { Submarine } \\
\text { terrace }\end{array}$} & \multicolumn{2}{|c|}{$\begin{array}{l}\text { Seaward } \\
\text { slope }\end{array}$} & \multicolumn{2}{|c|}{$\begin{array}{l}\text { All zones } \\
\text { combined }\end{array}$} \\
\hline & 1970 & 1971 & 1970 & 1971 & 1970 & 1971 & 1970 & 1971 & 1970 & 1971 & 1970 & 1971 \\
\hline $0-5$ & 5 & 6 & 72 & 31 & 314 & 326 & 275 & 451 & 135 & 428 & 801 & 1242 \\
\hline $6-10$ & 2 & 1 & 53 & 92 & 200 & 317 & 43 & 146 & 25 & 77 & 323 & 633 \\
\hline $11-15$ & 1 & 1 & 33 & 22 & 59 & 77 & 2 & 29 & 0 & 14 & 95 & 143 \\
\hline $16-20$ & 0 & 0 & 9 & 8 & 18 & 30 & 0 & 3 & 1 & 1 & 28 & 42 \\
\hline $21-25$ & 0 & 0 & 5 & 6 & 13 & 13 & 0 & 2 & 0 & 1 & 18 & 22 \\
\hline $26-30$ & 0 & 0 & 4 & 4 & 11 & 14 & 0 & 1 & 0 & 0 & 15 & 19 \\
\hline $31-35$ & 0 & 0 & 0 & 0 & 2 & 4 & 0 & 0 & 0 & 0 & 2 & 4 \\
\hline $36-40$ & 0 & 0 & 0 & 0 & 6 & 1 & 0 & 0 & 0 & 0 & 6 & 1 \\
\hline $41-45$ & 0 & 0 & 2 & 1 & 5 & 3 & 0 & 0 & 0 & 0 & 7 & 4 \\
\hline 46--up & 0 & 0 & 3 & 2 & 4 & 4 & 0 & 0 & 0 & 0 & 7 & 6 \\
\hline Totals & 8 & 8 & 181 & 166 & 632 & 789 & 320 & 632 & 161 & 521 & 1302 & 2116 \\
\hline
\end{tabular}

plus some recolonization from planulae settlement from 1969 to 1971 . Most of the increase that took place in the $0-5$ and $6-10 \mathrm{~cm}$ size ranges occurred in the submarine terrace and seaward slope zones where $A$. planci activity was the greatest. There has been a decrease in the number of colonies for most coral size ranges on the reef margin zone and parts of the inner half of the reef front zone because of the coral kill due to the algal bloom at Transect $\mathrm{A}$ and the outfall plume at Transect B. Most of the larger coralla are found in reef zones which were not subjected to much damage from $A$. planci.

Corallum Growth Form Distribution: If the observed increase in the total number of new colonies found at the station quadrats are due to recent coral planulae set-

Table 6. Distribution of corals by growth forms at Tanguisson Point from 1970 to 1971. Data from transects $\mathrm{A}, \mathrm{B}$, and $\mathrm{C}$ are combined.

\begin{tabular}{|c|c|c|c|c|c|c|c|c|c|c|c|c|}
\hline \multirow{2}{*}{$\frac{\text { Reef zones }}{\text { Growth from }}$} & \multicolumn{2}{|c|}{$\begin{array}{l}\text { Outer } \\
\text { reef flat }\end{array}$} & \multicolumn{2}{|c|}{ Reef margin } & \multicolumn{2}{|c|}{ Reef front } & \multicolumn{2}{|c|}{$\begin{array}{c}\text { Submarine } \\
\text { terrace }\end{array}$} & \multicolumn{2}{|c|}{$\begin{array}{l}\text { Seaward } \\
\text { slope }\end{array}$} & \multicolumn{2}{|c|}{$\begin{array}{l}\text { All zones } \\
\text { combined }\end{array}$} \\
\hline & 1970 & 1971 & 1970 & 1971 & 1970 & 1971 & 1970 & 1971 & 1970 & 1971 & 1970 & 1971 \\
\hline Massive & 0 & 0 & 19 & 18 & 128 & 122 & 41 & 44 & 14 & 56 & 202 & 240 \\
\hline Encrusting & 1 & 1 & 31 & 26 & 376 & 491 & 250 & 533 & 130 & 417 & 788 & 1468 \\
\hline Foliaceous & 0 & 0 & 0 & 0 & 0 & 0 & 0 & 0 & 5 & 8 & 5 & 8 \\
\hline Flabellate & 0 & 0 & 5 & 7 & 7 & 7 & 1 & 11 & 0 & 0 & 13 & 25 \\
\hline Corymbose & 0 & 0 & 13 & 24 & 29 & 50 & 0 & 4 & 0 & 2 & 42 & 80 \\
\hline Cespitose & 7 & 7 & 112 & 91 & 80 & 107 & 5 & 29 & 8 & 20 & 232 & 254 \\
\hline Arborescent & 0 & 0 & 1 & 0 & 8 & 12 & 0 & 0 & 0 & 2 & 9 & 14 \\
\hline Phaceloid & 0 & 0 & 0 & 0 & 4 & 0 & 1 & 6 & 2 & 1 & 7 & 7 \\
\hline Colomnar & 0 & 0 & 0 & 0 & 0 & 0 & 1 & 5 & 1 & 10 & 2 & 15 \\
\hline Solitary & 0 & 0 & 0 & 0 & 0 & 0 & 1 & 0 & 1 & 5 & 2 & 5 \\
\hline Totals & 8 & 8 & 181 & 166 & 632 & 789 & 320 & 632 & 161 & 521 & 1302 & 2116 \\
\hline
\end{tabular}


tlement, then a marked increase in the number of encrusting growth forms should be expected, since most newly settled corals go through an encrusting stage early in their development. Table 6 shows that an increase from 788 colonies in 1970 to 1468 colonies in 1971 has occurred in the number of encrusting growth forms. Eighty three percent of the above increase has taken place in the submarine terrace and seaward slope zones. There has been decreases in the number of colonies in the reef margin and reef front zones because of the corals killed by the algal bloom and outfall plume at transects $A$ and $B$ respectively. Seventeen percent of the increase in encrusting growth forms occurred in the reef front zone. Most of this increase actually took place on the outer part of the reef front zone where there was some $\mathrm{A}$. planci damage. This reef front increase of encrusting forms should coincide with a corresponding increase in the same zone for corallum diameter in the $0-5 \mathrm{~cm}$ range, but due to optimum growth conditions found at this zone, these new colonies are mostly distributed in the $6-10 \mathrm{~cm}$ size range (Table 5). The reef front zone also shows some gains in the number of corymbose and cespitose growth forms (Table 6) which are attributable to newly colonized corals, but as above they have apparently passed through their early encrusting growth form because of fast growth rates in this zone.

\section{Conclusions}

The increase in the total number of new coral colonies observed, the increase in species diversity, and the increase in the percentage of reef surface covered by living corals indicate that coral recovery is taking place at Tanguisson. Most of the coral recovery is taking place in those zones where $A$. planci infestation and the resulting damage was greatest. The increases observed for the percentage of reef surface covered by living corals is due to recolonization by the settlement of planulae and an increase in size of the few surviving patches or colonies of coral that remained after the starfish infestation period.

Based on a pre-Acanthaster value of 60 percent for the living coral surface coverage at the Tumon Bay control reef and an average gain of 3.0 percent coverage for the submarine terrace zone at Tanguisson Point, from 1970 to 1971 , it will then take the reef zone, there, about 20 years to attain the same degree of coverage found before $A$. planci predation. With a 50 percent pre-Acanthaster value for the living coral coverage at the control reef and an average gain of 1.6 percent coverage for the seaward slope zone at Tanguisson Point, from 1970 to 1971, it will then take the reef zone, there, about 31 years to attain the same degree of coverage as was found before $A$. planci predation.

The above recovery rates were determined from one year of data and a simple linear extrapolation based on the control reef values taken in 1967 and 1968. Actual growth rates of organisms seldom express themselves in a linear fashion, especially within an ecosystem as complex as that of a coral reef. The above reef recovery 
hypotheses are, at best, tenuous and based on gains in reef surface coverage by living corals. For the reef to attain the massive framework development that was once found in this region, it may take a much longer period of time-possibly as much as the 700 years predicted by the late T. F. Goreau (1969).

\section{Summary}

1. During 1968 at Tanguisson Point, over 95 per cent of the living reef corals were killed by $A$. planci in the submarine terrace and seaward slope zones.

2. The number of living coral colonies recorded on the Tanguisson Point transects has increased from 1302 in 1970 to 2116 in 1971 . Most of these new colonies have developed in the submarine terrace and seaward slope zones.

3. The total number of coral genera has increased from 30 to 36 on the Tanguisson Point transects and from 33 to 38 when additional genera observed between transects $\mathrm{A}$ and $\mathrm{C}$ are included.

4. During the study period, the total number of species has increased from 86 to 107 on the Tanguisson Point transects and from 96 to 111 when additional species observed between transects A and C are included. From 1970 to 1971 there were 23 species and 6 genera of corals recorded that were new to the Tanguisson Point transects. Of these new species 12 were also new to the Tumon Bay control reef. Of all the species recorded in 1970, only 9 were not recorded again in 1971 .

5. When increases in the number of genera and species are compared by reef zones at Tanguisson Point from 1970 to 1971, there has been little change in the zones where $A$. planci damage was minimal (except for damage caused by the alga bloom at Transect $\mathrm{A}$ and the power plant effluent at Transect B). The most significant increases have occurred on the submarine terrace and seaward slope zones where $A$. planci infestation and damage to reef corals was greatest.

6. The percentage of reef surface covered by living corals has increased on all reef zones at Tanguisson Point except the reef margin at Transect A (reduction caused by alga bloom) and the inner reef flat, reef margin, and reef front zones at Transect B (reduction caused by power plant outfall). The greatest relative increase in the percentage of reef surface covered by living corals has occurred on the submarine terrace and seaward slope zones.

7. During the study period increases in coral size has been greatest in the $0-5 \mathrm{~cm}$ range and in the 6-10 range. Most of these increases have occurred in the submarine terrace and seaward slope zones.

8. During the study period greatest changes in the distribution of coral growth forms has been an increase of the encrusting types. Most of this increase has occurred in the submarine terrace and seaward slope zones. 


\section{LITERATURE CITED}

Chesher, R. H. 1969a. Destruction of Pacific corals by the sea star Acanthaster planci. Science 165: 280-283.

1969b. Acanthaster planci, impact on Pacific coral reefs. Final Report to U.S. Department of Interior. Westinghouse Research Laboratories, No. 69-951-Ocean-RS. $59 \mathrm{p}$.

Cloud, P.E., Jr. 1951. Reconnaissance geology of Guam and problems of water supply and fuel storage. Military Geology Branch, U.S. Geol. Sur., open file report. 50p.

- 1954. Superficial aspects of modern organic reefs. Sci. Monthly 79 (4): 195-208.

___ 1959. Submarine topography and shoal-water ecology. Part 4 of Geology of Saipan, Mariana Islands. U.S. Geol. Surv. Prof. Pap. 280-K: 361-445.

Emery, K. O. 1962. Marine geology of Guam. U.S. Geol. Surv. Prof. Pap. 403-B: 1-76.

Goread, T. F. 1969. Post pleistocene urban renewal in coral reefs. Micronesica 5 (2): 323-326.

Porter, W. P. 1972. Predation by Acanthaster and its effect on coral species diversity. Amer. Natur. 106 (950): 487-492.

RandalL, R. H. 1971. Tanguisson-Tumon, Guam, reef corals before, during and after the Crownof-Thorns starfish (Acanthaster planci) predation. Master of Science Thesis, University of Guam. 119 pp.

Stearns, H. T. 1940. Geologic history of Guam. Geol. Soc. Amer. Bull. 52 (12): 1948. [Abstract].

TAYAMA, R. 1952. Coral reefs of the South Seas. Japan Hydrogr. Off. Bull. 11: 1-292. [Japanese and English].

Tracey, J. I., Jr., S. O. Schlanger, J. T. Stark, D. B. Doan, and H. D. May. 1964. General geology of Guam. U.S. Geol. Surv. Prof. Pap. 403-A: 1-104.

TsudA, R. T. (compiler). 1971. Status of Acanthaster planci and coral reefs in the Mariana and Caroline Islands, June 1970 to May 1971. Technical Report No. 2, Marine Laboratory, University of Guam. 127 pp.

Wells, J. W. 1954. Recent corals of the Marshall Islands. U.S. Geol. Surv. Prof. Pap. 260-I: 385486.

, 1956. Scleractinia, p. F328-F444. In R. C. Moore [ed.] Treatise on Invertebrate Paleontology. Chap. F. Geol. Soc. Amer. and Univ. Kansas Press.

\section{DISCUSSION}

YAMAzATo: This is not a question, but a reference to your presentation. In Okinawa, we have been experiencing the similar incidence of Acanthaster explosion. But here we have rapid growth and spread of soft corals.

Randall: At Tanguisson Point there was no significant increase in the percentage of reef substrate covered by soft corals, but at other places along the NW coast there has been a recolonization of reef surface by soft corals.

EDWARDS: Have the star-fish disappeared from the area?

RANDALL: Most have left the study region, but a few can still be found in about normal population densities at Tanguisson Point. This population pressure is of more significance with the reduced percentage of coral cover now found than when the reef surface was covered 45 to 60 percent by living corals. 